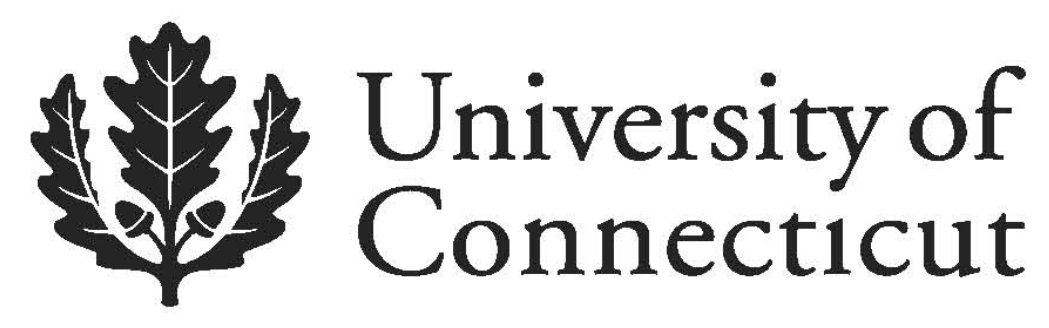

Department of Economics Working Paper Series

\title{
Does Financial Development Volatility Affect Industrial Growth Volatility?
}

Ho-Chuan Huang

Tamkang University

WenShwo Fang

Feng Chia University

Stephen M. Miller

University of Nevada, Las Vegas

University of Connecticut

Working Paper 2012-45

November 2012

365 Fairfield Way, Unit 1063

Storrs, CT 06269-1063

Phone: (860) 486-3022

Fax: (860) 486-4463

http://www.econ.uconn.edu/

This working paper is indexed on RePEc, http://repec.org 


\title{
Does Financial Development Volatility
}

\section{Affect Industrial Growth Volatility?}

\author{
Ho-Chuan (River) Huang \\ Department of Banking and Finance \\ Tamkang University \\ WenShwo Fang \\ Department of Economics \\ Feng Chia University \\ Stephen M. Miller* \\ Department of Economics \\ University of Nevada, Las Vegas
}

Nov. 12, 2012

\begin{abstract}
This paper investigates whether volatility of financial development plays a role in determining industrial growth volatility. Three key findings emerge. First, overwhelming evidence supports the view that more volatile financial development raises the industrial volatility in sectors that rely more on external liquidity. Second, the harmful effect of financial volatility on industrial volatility mainly works through the increase in fluctuations of the growth of real value added per firm and the number of firms, with the former effect more prominent. Third, both the volatilities of the banking sector and the stock market positively associate with higher industrial growth volatility, which contrasts sharply with the finding in the existing literature that financial structure generally does not matter.
\end{abstract}

Keywords: Financial Development, Financial Volatility, Industrial Growth Volatility.

JEL Classification: E32, G2, O16

* Corresponding author: Professor Stephen M. Miller, Department of Economics, University of Nevada, Las Vegas, Las Vegas, NV, 89154-6005, USA; e-mail: stephen.miller@unlv.edu. The authors gratefully acknowledge Claudio Raddatz for sharing part of his data used in this paper. Financial support from the National Science Council (Taiwan, R.O.C.) via grant number NSC 97-2410-H-032-002-MY3 is greatly acknowledged. Any remaining errors are our own responsibility. 


\section{Introduction}

The theoretical and empirical growth literature has extensively explored the effect of financial development on economic growth. Theoretically, financial intermediaries and financial markets mitigate the costs of acquiring information, enforcing contracts, and making transactions. That is, the development of financial systems changes the incentives and constraints facing economic agents through producing information and allocating capital, monitoring firms and exerting corporate governance, ameliorating risk, pooling saving and easing exchange, with positive ramifications on economic growth (e.g., Greenwood and Jovanovic, 1990; Bencivenga and Smith, 1991; King and Levine, 1993a; Acemoglu and Zilibotti, 1997; and Khan, 2001). Empirically, cross-country studies (e.g., Goldsmith, 1969; King and Levine, 1993b; Levine and Zervos, 1998; Levine et al., 2000; Beck and Levine, 2004; and McCaig and Stengos, 2005) offer strong and robust evidence supporting the view that both well-functioning banking systems and better-developed stock markets independently spur economic growth. That is, banking systems and stock markets provide different, but complementary, growth-enhancing financial services to the economy. Moreover, the overall level of financial development matters for economic growth, rather than the development of a specific component of the financial systems. See Levine (1997, 2005), Ang (2008) and Beck (2009) for more detailed survey on the finance-growth nexus.

Policy makers identify output growth stability as one of several macroeconomic policy objectives (Yellen and Akerlof, 2006; and Mishkin, 2009). Thus, in addition to the growth effect of financial development, another strand of the growth literature focuses on assessing whether financial sector development influences growth volatility as well. ${ }^{1}$ Theory offers ambiguous predictions about the effect of financial development on growth volatility. For example, Bernanke

\footnotetext{
1 Many adverse effects occur because of higher output growth volatility such as lower economic growth (Ramey and Ramey, 1995; Kose et al., 2005, 2006; Aghion et al., 2010), worsened income distribution (Breen and Garcia-Peñalosa 2005), and higher output and employment costs (Benigno and Ricci, 2011). A successful macroeconomic policy to stabilize or reduce growth volatility depends on knowing the sources of that volatility.
} 
and Gertler (1989) and Kiyotaki and Moore (1997) argue that financial constraints on firms can play a key role in the propagation of the business cycle and can eventually lead to higher oscillations. Accordingly, well-developed financial systems, by removing or alleviating financial constraints, can dampen output volatility. Bacchetta and Caminal (2000), Aghion et al. (2004), and Morgan et al. (2004) show that the ultimate (positive or negative) effect of financial development on volatility depends on real or monetary shocks, intermediate versus early and later stages of a country's financial development, and credit supply or demand shocks, respectively. The existing cross-country empirical evidence on the finance-volatility relationship also proves mixed, at best. Denizer et al. (2002) find that countries with better developed financial systems experience smaller fluctuations in per capita output growth. Bekaert et al. (2006) establish that financial liberalization often results in lower (consumption) growth volatility. Acemoglu et al. (2003) assert that the volatility effect of financial development diminishes once one controls for institutional variables. Beck et al. (2006) conclude that no robust relationship exists between financial development and aggregate economic volatility. Finally, Levchenko et al. (2009) find strong evidence supporting the view that financial liberalization increases output volatility.

Larrain (2006) and Raddatz (2006) implement the methodology of Rajan and Zingales (1998, hereafter, RZ) to revisit the effect of financial development on industrial growth volatility, using cross-country, cross-industry (firm) data. In contrast to the conventional cross-country studies, the RZ cross-country, cross-industry approach brings several advantages to the analysis: (i) increases the degrees of freedom, thus, improving the precision of the estimated coefficients, (ii) addresses the issue of omitted variables, and most important, (iii) provides a causal interpretation of the effect of financial development on sectoral volatility. Moreover, the RZ model also permits the identification of the channels through which financial development affects growth volatility.

More specifically, Larrain (2006) employs the RZ specification to examine whether better access to bank credit decreases or increases growth volatility. The ambiguous effect depends on whether firms face more financial constraints during output contractions (i.e., more credit decreases 
volatility) or expansions (i.e., more credit increases volatility). By regressing industrial volatility (the standard deviation of the detrended output of industry $j$ in country $k$ ) onto the interaction of external dependence (in $j^{\text {th }}$ industry) and financial development (in $k^{\text {th }}$ country) along with other controls, Larrain (2006) finds a significantly negative coefficient on the interaction term, arguing that lower volatility output occurs in sectors with higher external dependence and in countries with better financial development. Raddatz (2006) uses the same framework to investigate whether financial development leads to a larger reduction in output volatility in industries with high liquidity needs. By regressing industrial volatility onto the interaction between liquidity needs and financial development, Raddatz shows that financial development reduces the volatility of industries that require large amounts of liquidity. That is, financial development reduces growth volatility through external financial dependence in Larrain (2006) and liquidity needs in Raddatz (2006).

This paper complements Larrain (2006) and Raddatz (2006) and evaluates for a given level of financial development, whether the volatility of financial development affects industrial volatility. In this respect, many extant theoretical and empirical studies document that macroeconomic variability or uncertainty relates to economic activity. ${ }^{2}$ For instance, Pindyck (1991) asserts that inflation uncertainty, increasing the uncertainty of the potential returns of investment projects, contributes to lower investment and output growth. Dotsey and Sarte (2000) find that, although inflation adversely affects long-run growth, inflation uncertainty increases average growth rates through a precautionary saving motive. Ramey and Ramey (1995) show that countries with higher growth volatility experience lower economic growth, and Hnatkovska and Loayza (2005) verify this negative relationship between macroeconomic volatility and long-term economic growth. Fountas et al. (2006) confirm that inflation uncertainty exerts a negative effect on growth, but output growth uncertainty positively affects growth. Loayza and Ranciere (2006) demonstrate a positive long-run linkage between financial development and output growth

\footnotetext{
${ }^{2}$ In this paper, we use volatility, variability, and uncertainty (of financial development) interchangeably.
} 
coexisting with a mostly negative short-run association between financial fragility, namely, banking crises and financial sector volatility, and output growth. More recently, Fatás and Mihov (2012) find that fiscal policy volatility lowers economic growth. Lin and Huang (2012) demonstrate that banking sector volatility exerts a negative effect on the growth of industries that rely more on external finance.

The Great Moderation initiated a literature assessing the causes of the decline in output growth volatility. For example, Blanchard and Simon (2001) find that during the Great Moderation, the reduction of US GDP growth volatility mainly reflects a decline in the volatility of government spending, consumption, and investment as well as inflation. Eggars and Ioammides (2006) decompose US output growth volatility by one-digit industry and find that around half of the drop in the volatility between the pre- and post-1982 periods reflects the decline of the volatility of the production sector. In searching for the source of industrial volatility, we assess whether financial volatility causally affects sectoral volatility, and explore the channels by which financial volatility influences the extent of industrial volatility. This interesting issue shows how shocks propagate through the economy. If a financial crisis leads to higher financial volatility, which sectors experience more output growth volatility from this higher financial volatility?

We augment the data used in Raddatz (2006) with additional variability measures of financial development, finding overwhelming evidence that more financial volatility significantly increases industrial growth volatility. In particular, countries with higher volatility of financial intermediary development experience higher relative sectoral volatility in industries more dependent on external liquidity. We, then, proceed to investigate the possible mechanisms through which such effects could work. The empirical results suggest that the increase in sectoral volatility caused by the volatility of financial intermediaries mainly works through fluctuations in the variability of output growth per firm and of the number of firms, with the effect of the first term more pronounced. We confirm Raddatz's (2006) finding that the development of financial intermediaries, rather than the development of stock markets, mainly causes the reduction of 
industrial volatility. As such, while the existing literature finds that financial structure (bank-based versus market-based) proves irrelevant to economic growth, it does matter for the reduction of growth volatility. We provide fresh evidence that both the volatilities of financial intermediaries and equity markets positively and significantly affect industrial growth volatility. Sensitivity checks indicate that our results remain robust to alternative measures of country-level financial volatility and indicators of industry-level liquidity needs.

The paper is organized as follows. Section 2 describes the empirical strategy introduced by Rajan and Zingales (1998) and used by Raddatz (2006) to assess the causal effect of financial development on output growth and volatility, respectively. In particular, we include an interaction of a measure of industry-level liquidity needs and an indicator of country-level financial volatility into an otherwise standard RZ specification. We also use similar regressions to evaluate whether financial structure matters for the reduction of industrial volatility and to assess the channels by which the level and volatility of financial development influence sectoral volatility. Section 3 documents the data sources. Section 4 presents our main results that industries with larger liquidity needs exhibit more volatility in countries with more uncertain financial development. Section 5 provides some robustness checks. Section 6 concludes.

\section{Empirical Strategy}

In the seminar study, Rajan and Zingales (1998) assess whether the industries mostly dependent on external finance grow faster in countries with better developed financial institutions and markets. They show that industries with a greater dependence on external finance grow faster in more financially developed countries. Raddatz (2006) employs the same specification to explore whether sectors with high liquidity needs exhibit relatively more volatility in countries with less developed financial systems. He finds that financial development results in larger reductions in the volatility of industries with higher liquidity needs. Other studies that implement the Rajan and Zingales’ (1998) approach include, for example, Cetorelli and Gambera (2001), Beck and Levine (2002), Claessens 
and Laeven (2003, 2005), Braun and Larrain (2005), Kroszner et al. (2007), Beck et al. (2008), Gupta and Yuan (2009), and Levchenko et al. (2009).

Following Rajan and Zingales (1998) and Raddatz (2006), we test the hypothesis that financial volatility exerts a relatively larger effect on the volatility of industries with high liquidity needs. In this respect, we augment the framework of Raddatz (2006) by including an interaction term between the measure of financial volatility and the sectoral measure of liquidity needs to examine whether financial volatility exerts a larger effect on the sectoral volatility in industries that need more liquidity. We specify the benchmark regression as follows:

$$
V_{i k}^{G}=\alpha_{0}+\alpha_{1} D_{i}^{I}+\alpha_{2} D_{k}^{C}+\beta_{1}\left(L N_{i}^{*} D E V_{k}^{F}\right)+\beta_{2}\left(L N_{i}^{*} V_{k}^{F}\right)+\beta_{3} O C_{i k}+\varepsilon_{i k}
$$

where subscripts $i$ and $k$ denote the $i^{\text {th }}$ industry and the $k^{\text {th }}$ country, respectively. The dependent variable, $V_{i k}^{G}$, measured as the standard deviation of the growth of real value added (VA), is the volatility of industry $i$ in country $k$. We include industry and country dummy variables to capture the influence of effects specific to each industry $\left(D_{i}^{I}\right.$ ) or country $\left(D_{k}^{C}\right)$, respectively, and to address concerns about omitted variable bias and reverse causality that commonly plague cross-country regressions.

The first main explanatory variable, the interaction of liquidity needs $\left(L N_{i}\right)$ (measure of liquidity needs of the $i^{\text {th }}$ industry) and financial development $\left(D E V_{k}^{F}\right)$ (indicator of financial development of the $k^{\text {th }}$ country), determines whether financial development exerts a causal effect in the reduction of industrial volatility in sectors that need liquidity. Raddatz (2006) generally finds a negative, significant, and economically large coefficient $\left(\beta_{1}\right)$, supporting the view that financial development leads to a larger decrease in volatility in sectors with higher liquidity needs. Our primary interest relates to the second explanatory variable, the interaction between liquidity needs and financial volatility $\left(V_{k}^{F}\right)$ (indicator of financial volatility of the $k^{\text {th }}$ country), which tests whether sectors that need more liquidity exhibit larger volatility in a country with higher financial volatility. 
If the volatility of financial development leads to an increase (decrease) in the volatility of sectors with higher liquidity needs, we expect a significantly positive (negative) coefficient $\left(\beta_{2}\right)$. Finally, Model (1) includes the other control variables $\left(O C_{i k}\right)$, a set of extra determinants of industrial volatility, and the error term $\left(\varepsilon_{i k}\right)$.

Beck and Levine (2002), Demirgüç-Kunt and Maksimovic (2002) and Levine (2002) generally find that, while overall financial development strongly associates with economic growth, no support exists for either the bank-based or the market-based view. That is, a country's financial structure does not influence its economic growth. In contrast, in the case of growth volatility, Larrain (2006) and Raddatz (2006) find that both well-developed banking systems and stock markets exert a dampening effect on (firm and industry) volatility, and the development of financial intermediaries lowers industrial volatility more than stock market development. As an extension, we also estimate the effect of stock market volatility on the sectoral volatility in industries with higher liquidity needs. We specify the regression as follows:

$$
\begin{aligned}
V_{i k}^{G}=\alpha_{0}+\alpha_{1} D_{i}^{I}+\alpha_{2} D_{k}^{C} & +\beta_{1}\left(L N_{i} * D E V_{k}^{F}\right)+\beta_{2}\left(L N_{i} * V_{k}^{F}\right) \\
& +\beta_{3}\left(L N_{i}^{*} D E V_{k}^{S M}\right)+\beta_{4}\left(L N_{i} * V_{k}^{S M}\right)+\beta_{5} O C_{i k}+\varepsilon_{i k},
\end{aligned}
$$

Model 2 is the same as Model 1 except for the inclusion of two additional interaction terms of liquidity needs with stock market development $\left(L N_{i} * D E V_{k}^{S M}\right)$ and liquidity needs and stock market volatility $\left(L N_{i} * V_{k}^{S M}\right)$. First, Larrain (2006) and Raddatz (2006) argue that a well-functioned stock market can provide liquidity to smooth fluctuations of sales and inventory of firms and real value added growth of industries. We, thus, expect a significantly negative coefficient $\left(\beta_{3}\right)$. Second, obviously, higher stock market volatility makes industries more uncertain (difficult) to acquire the necessary liquidity and, hence, exhibit larger variability in their real value added growth. As such, we expect to find a significantly positive coefficient $\left(\beta_{4}\right)$, supporting the idea that stock market development volatility exerts a larger (and increasing) effect on the sectoral volatility in industries with larger liquidity needs. 
Finally, we also investigate the channels through which the level and volatility of financial development affect the volatility of industries with high liquidity needs. In particular, we specify the regression as follows:

$$
V C_{i k}^{G}=\alpha_{0}+\alpha_{1} D_{i}^{I}+\alpha_{2} D_{k}^{C}+\beta_{1}\left(L N_{i}^{*} D E V_{k}^{F}\right)+\beta_{2}\left(L N_{i} * V_{k}^{F}\right)+\beta_{3} O C_{i k}+\varepsilon_{i k}
$$

Model 3 is identical to Model 1 except for the dependent variable. Raddatz (2006) argues that we can define the dependent variable $\left(V C_{i k}^{G}\right)$ as the volatility of the growth of real value added per firm, the volatility of the growth in the number of firms, or the covariance between the two variables. Therefore, Model 3 explores how financial volatility along with the level of financial development affects each of these three components of industrial growth volatility.

Ordinary least squares (OLS) estimation of Models 1, 2, and 3 with standard errors corrected for heteroskedasticity can still produce biased coefficients due to the endogeneity of financial development. Thus, we also report estimates using two-stage least squares (2SLS) with legal origin variables from La Porta et al. $(1997,1998)$ as the instruments as suggested by Beck et al. (2000) and Levine et al. (2000).

\section{Data Sources and Description}

This paper uses data mainly from Raddatz (2006), who shows that financial development exerts a significant causal effect in reducing industrial volatility via liquidity provision. Below, we provide a brief description of the relevant variables in country-industry level, industry level, and country level, respectively. More detailed explanation of the data appears in Raddatz (2006).

\subsection{Country-Industry Level Variables}

We measure industrial volatility at the country-industry level by the standard deviation of real value added growth for each 4-digit ISIC industry in each country. The whole sample consists of an unbalanced panel of 47 countries with data on at least 10 of 70 4-digit ISIC industries. The set of other control variables $\left(O C_{i k}\right)$ includes the initial share of a sector in a country's manufacturing value added to capture the likelihood that a more advanced (mature) industry is systematically more 
stable, and the (logarithm of the) initial number of firms to capture the (law of large numbers) notion that industrial volatility lowers as the number of firms grows larger. To determine how the interactions between liquidity needs and financial development and its volatility affect sectoral volatility, we follow Raddatz (2006) and consider three potential measures: (i) the variance of the growth of real value added per firm, (ii) the variance of the growth in the number of firms, and (iii) the covariance between the growth of real value added per firm and the growth in the number of firms. Raddatz (2006) calculated all variables over the 1981-1998 period. The data come originally from the United Nations Industrial Development Organization, Industrial Statistics Database (UNIDO).

\subsection{Industry Level Variables}

The proxy measure of liquidity needs at the industry level uses US data from Compustat during the 1980-1989 period. ${ }^{3}$ We use as the main proxy for liquidity needs the ratio of inventories to sales, which represents the portion of sales revenue needed to finance inventory investment. Thus, a higher value of this ratio denotes a higher level of external liquidity needs. For robustness checks, we follow Raddatz (2006) and use four alternative proxies for liquidity needs -- (i) the cash conversion cycle, which equals the mean age of inventories plus the mean age of accounts receivables minus the mean age of accounts payable; (ii) the ratio labor cost to sales, which evaluates the ability of a firm to finance its ongoing labor cost from its sales revenue; (iii) the portion of short-term debt to sales, which appraises not only the real use of external liquidity but also the ability of a firm to pay its current liabilities through ongoing income, and (iv) the measure of external financial dependence, which equals the difference between investment and cash flow relative to investment.

${ }^{3}$ Raddatz (2006, p. 684) borrows from Rajan and Zingales (1998) an indirect approach to measure liquidity needs. Both papers argue that the liquidity needs measure based on US industrial data can proxy for liquidity needs of a specific industry across all countries in the sample. This choice relies on two assumptions - technological factors explain differences in liquidity needs across industries and these technological factors persist across countries within industries. See Raddatz (2006) and Rajan and Zingales (1998) for more details. 


\subsection{Country Level Variables}

The primary measure of country-level financial development (the size of the financial system) uses the ratio of private credit by deposit money banks and other financial institutions to GDP over the 1980-1998 period. Accordingly, financial volatility equals the standard deviation of the financial development over the same period. We also use the range (difference between the maximum and minimum values) of private credit to GDP over the period 1980-1998 as another indicator of financial volatility. Further, we consider two common measures of financial intermediary development -- liquid liabilities to GDP (the ratio of currency plus demand and interest-bearing liabilities of banks and other financial intermediaries to GDP) and deposit money banks assets to GDP. Likewise, the corresponding volatility measures equal their standard deviations.

To explore whether financial structure matters for the decrease or increase of growth volatility in industries with higher liquidity needs, we also consider three indicators of stock market development. The first indicator measures the size of the stock markets relative to the size of the economy (i.e., stock market capitalization to GDP, which equals the ratio of the value of listed shares to GDP). The second indicator measures the liquidity (or activity) of a stock market relative to its size (i.e., the stock market turnover ratio, which equals the ratio of the value of total traded shares to market capitalization). The third indicator measures the degree of liquidity that stock markets provide to the economy (i.e., stock market total value traded to GDP, which equals the ratio of total shares traded on the stock exchange to GDP). All the financial development data come from the Financial Development and Structure Database of Beck et al. (2000, 2010).

Finally, we interact liquidity needs with other macroeconomic determinants of growth volatility to determine if the effects of financial development and its volatility on the sectoral volatility continue to hold. Specifically, we consider four variables: (i) the level of economic development (Koren and Tenreyro, 2007) (i.e., the logarithm of real per capita GDP); (ii) the inflation rate (Blanchard and Simon, 2001) (i.e., the logarithmic difference in the GDP deflator); (iii) the government size (Fatás and Mihov, 2001; Andrés et al., 2008) (i.e., the ratio of 
government spending to GDP), and (iv) the trade openness (di Giovanni and Levchenko, 2009) (i.e., the ratio of imports plus exports to GDP). We average all macroeconomic variables over the 1980-1998 period, and the data come from the WDI (World Development Indicators, 2009). Furthermore, we also include the respective volatilities (measured by the standard deviations) of those four variables over the same period to assess whether the effects of financial volatility on growth volatility remain robust to the inclusion of other macroeconomic volatility variables.

Table 1 provides the basic statistics for the relevant variables and Table 2 displays detailed (country-level) figures of the primary measures of financial development (i.e., private credit) and stock market development along with their corresponding volatility measures. Note that, since the United States (US) data are used to calculate the external dependence, following Rajan and Zingles (1998, p. 574), we drop the US in all regressions.

\section{Empirical Results}

\subsection{Financial Development and Volatility on Industrial Volatility}

Table 3 reports empirical results from Model 1, where we regress industrial volatility (the standard deviation of real value added growth) across industries and countries onto the interaction terms of the industrial liquidity needs (inventories over sales), and country-level financial development (private credit to GDP) and its volatility (volatility of private credit to GDP). We include country and industry dummies to control for unobserved country-specific and industry-specific characteristics, but omit the findings for brevity. The even columns include two additional control variables -- (i) the initial share of a sector in a country's manufacturing value added and (ii) the logarithm of the initial number of firms. We report three distinct sets of coefficients estimates. Columns (1) and (2) record the OLS results. Columns (3) and (4) show the 2SLS results with financial development instrumented by the legal origins of the country. Columns (5) and (6) present the 2SLS results with liquidity needs instrumented by the inventory-to-sales ratio measured in the 1970s in addition to the instrument of the legal origins of the country. 
The first row of Table 3 shows that the estimated coefficients for the interaction term of liquidity needs and private credit to GDP are all significantly negative at the 1-percent level, irrespective of the set of conditioning variables or the estimation approach. These results confirm Raddatz’s (2006) hypothesis and findings that financial development reduces sectoral volatility in industries more reliant on external liquidity. Stated differently, financial underdevelopment raises the relative industrial volatility in those sectors that require large amounts of liquid funds to operate. To see the economic magnitude of the effect, the Differential Volatility section of Table 3 reports the estimated effect corresponding to an improvement in financial development from the 25th (the level of financial development of Colombia) to 75th (the level of financial development of Austria) percentile level on the difference in sectoral volatility between the industries located at the 25th (boxes of paper and paperboard industry, ISIC 3412) and 75th (electric industrial machinery industry, ISIC 3831) percentile levels of liquidity needs. ${ }^{4}$ Since financial development is probably an endogenous regressor, we discuss the empirical results using the 2SLS(I) approach as our benchmark with financial development instrumented by legal origin in each country. According to the estimates of columns (3) and (4), the magnitude of the standard deviation between these two industries decreases by 7.236 and 5.566 percentage points, without and with additional controlling variables, as a result of the improvement in financial development. Different estimation results such as OLS in columns (1) and (2) or 2SLS(II) in columns (5) and (6) with different instruments continue to confirm that the volatility-reduction effects of financial development remain economically large.

Second, our major contribution tests whether, given the level of financial development, the volatility of financial development plays a causal role in affecting the volatility of industries with higher liquidity needs. To do so, we interact the volatility of private credit to GDP with liquidity

\footnotetext{
${ }^{4}$ Since we use more updated data (on Private Credit) over the 1980-1998 rather than 1980-1995 period as in Raddatz (2006), the ranking of the average level of financial development for each country differs from Raddatz's (2006) ranking.
} 
needs in the regressions. The second row of Table 3 presents our results with alternative specifications and estimation methods. The estimates for the interaction term are all significantly positive at the 1-percent level. That is, more financial volatility increases sectoral volatility across industries, especially those industries that depend more on external liquidity. In the Differential Volatility section, the parameters estimated by the 2SLS(I) in columns (3) and (4) indicate that an increase in the volatility of financial development is equivalent to moving from the extent of financial volatility of Tunisia (25th percentile) to the level of Hong Kong (75th percentile) increases the difference in standard deviation between the boxes of paper and paperboard industry and the electric industrial machinery industry by 3.225 and 2.757 percentage points, respectively, for the two specifications. Analogous calculations for the other columns further demonstrate that financial volatility exerts a significant positive causal influence on the industrial volatility. Thus, both the level and the stability of financial development exert independent effects on industrial volatility through the provision of liquidity needs. According to the estimates of the two Differential Volatility sections, in absolute values, the positive effect of financial volatility on industrial volatility roughly equals half of the negative effect of financial development on that volatility.

Two extra features deserve further discussion. First, irrespective of the estimation approach, the estimates for the additional controls all prove significantly negative at the 1-percent level, suggesting that industries with a larger initial share of manufacturing value added or a larger initial number of firms exhibit less volatility. Second, the Hansen-J test statistics for overidentification are all small and insignificant. We cannot reject the null hypothesis of the instruments validity (exogeneity) at conventional significance levels in any of the two 2SLS regressions. ${ }^{5}$ The estimates on the interactions $\left(\beta_{1}\right.$ and $\beta_{2}$ ) by OLS are much smaller (in absolute values) than those obtained

\footnotetext{
${ }^{5}$ As suggested in Raddatz (2006), we focus on the results obtained by the 2SLS(I) approach with only financial development instrumented by legal origins. In cases where the overidentification tests are rejected, we consider further instrumenting the liquidity needs variables by the inventory-to-sales ratio measured in the 1970s as the 2SLS(II) specification. In a few cases where the overidentification tests do not pass, we further instrument the measure of financial development with additional religion, years of independence, latitude, settler mortality, and ethnic fractionalization as suggested in McCaig and Stengos (2005).
} 
by 2SLS. This finding probably reflects the attenuation bias caused by the use of imperfect indicators of financial development, financial volatility, and liquidity needs.

\subsection{Stock Market Development and Volatility on Industrial Volatility}

In addition to the growth effect of financial intermediary development, the literature also addresses the comparative role of financial structure (i.e., bank-oriented versus market-oriented financial system) in economic growth (e.g., Beck and Levine, 2002; Demirgüç-Kunt and Maksimovic, 2002; and Levine, 2002). The general message from this research suggests that economic growth depends on a well-developed financial system, but that the precise composition of the financial system is of second-order importance. Larrain (2006) and Raddatz (2006) show, however, that while both well-functioning financial intermediaries (banks) and arm’s-length stock markets can smooth volatilities of firms and industries, the financial intermediary development effect dominates the stock market development effect. ${ }^{6}$

The results reported in the first two rows of Table 4 confirm the view that the development of financial intermediaries plays a much more prominent role in the reduction of industrial volatility than the development of stock markets, measured by either stock market capitalization, the total value of traded stocks, or the stock market turnover ratio. The coefficients on the interaction term of liquidity needs and private credit to GDP in all regressions are significantly negative at the 1- or 5-percent levels. In contrast, although the coefficients on the interaction between liquidity needs and different measures of stock market development enter the regressions with a negative sign, the coefficients are generally insignificant. Thus, primarily the development of financial intermediaries (banks) rather than the development of stock markets lessens the volatility of industries with high liquidity needs. Stock markets play no or, at best, a weak role in determining sectoral volatility.

\footnotetext{
${ }^{6}$ Larrain (2006) argues that the reduction of (idiosyncratic) volatility occurs mainly via countercyclical borrowing, and Raddatz (2006) argues that the volatility dampening mainly occurs through the provision of liquidity needs by financial development.
} 
Our main contribution explores whether the volatilities of bank and stock market development relate to the volatility of industries with high liquidity needs. Thus, in addition to the interaction terms involving the volatility of private credit to GDP, we include an extra interaction term of industrial-level liquidity needs and three country level measures of stock market development volatility -- the standard deviations of (i) stock market capitalization, (ii) the total value of stock market trades, and (iii) the stock market turnover ratio over the 1980-1998 period. The results in the third row of Table 4 confirm our previous findings in Table 3 that the interaction of liquidity needs and volatility of private credit to GDP produces a significantly positive effect in all regressions, supporting the hypothesis that higher volatility of bank development increases industrial volatility more in sectors with higher liquidity needs. Economically, the Differential Volatility row shows that the magnitudes are sizable, but generally smaller than those reported in Table 3.

The fourth row of Table 4 reports the effects of alternative measures of volatility of stock market development on sectoral volatility. In contrast to the weak stock market effect on the sectoral volatility, the interaction between liquidity needs and each measure of stock market development volatility always enters the regression with a significantly positive effect at the 10-percent level or better. Thus, the empirical evidence shows that industries requiring higher liquidity exhibit larger growth volatility in countries with more volatile stock market development. The estimates indicate that the effects are also economically sizable. Taking stock market capitalization, for example, the estimated coefficients for stock market capitalization reported in columns (1) and (2) of Table 4 imply that the volatility differentials between the industries with liquidity needs at the 25th (boxes of paper and paperboard industry, ISIC 3412) and 75th (electric industrial machinery industry, ISIC 3831) percentile levels are approximately 1.109 and 0.832 percentage points higher, without and with extra controlling variables, in a country with the volatility of stack market capitalization at the 75th (the volatility of Chile) percentile compared with a country at the 25th (the volatility of Indonesia) percentile. The effects grow even larger when we 
consider the total value of stock market trades and the stock market turnover ratio as volatility measures.

\subsection{Decompositions of the Change in Industrial Volatility}

The previous section demonstrates that better-developed financial intermediaries smooth the industrial volatility while more volatile financial intermediary development raises sectoral volatility in industries with higher liquidity needs. An equally interesting question examines how changes in industrial volatility occur. Raddatz (2006) notes three possible channels through which financial development can affect the industrial growth volatility of real value added -- (i) the change in the variance of real value added per firm growth, (ii) the change in the variance of number of firms growth, and/or (iii) the change in the covariance of real value added per firm growth and number of firms growth. Table 5 summarizes the estimation results of regressing these three dependent variables on the interaction of liquidity needs and private credit to GDP and the interaction of liquidity needs and the volatility of private credit to GDP, without and with additional conditioning information set.

The first row of Table 5 shows that the estimate on the interaction of liquidity needs and private credit to GDP is significantly negative at the 1-percent level when the dependent variable is either the variance of real value added per firm growth or the variance of number of firms growth, and significantly positive at the 5-percent or 10-percent levels when the dependent variable is their covariance. These results generally match Raddatz's (2006) findings that the advance of financial development lowers both the variance of the real value added per firm growth and the variance of the number of firms growth, but raises the covariance between these two terms. The effect of financial development on the reduction of the volatility of real value added per firm growth substantially exceeds the corresponding effect on the other two components. Thus, deeper financial intermediation reduces sectoral volatility by providing liquidity to smooth fluctuations in real value added per firm growth and the number of firms growth, but the volatility-dampening effect of the first term is more important. 
To examine the channels by which financial volatility affects the industrial volatility with high liquidity needs, we focus on the coefficient estimates on the interaction term of liquidity needs and volatility of private credit with alternative dependent variables. The results appear in the second row of Table 5. While significantly positive estimates exist on the interaction terms at the 5-percent level (or better) with the variance of the real value added per firm growth and/or the variance of the number of firms growth as the dependent variable, the coefficients become insignificantly negative for the covariance between real value added per firm growth and number of firms growth as the dependent variable. Accordingly, the evidence reveals that financial volatility raises industrial volatility by increasing the variance of the real value added per firm growth and the variance of the number of firm growth. The magnitudes of the parameter estimates suggest a similar pattern as in the case of financial development, the volatility-boosting effect of financial volatility comes mainly from smoothing fluctuations in the production of individual firms rather than reducing fluctuations in the number of firms.

\section{Robustness Check}

This section provides some robustness checks to assess whether our main findings continue to hold with alternative measures of certain key variables. First, we consider alternative proxies for financial development volatility. Specifically, we use the range, rather than the standard deviation, of private credit to GDP over the 1980-1998 period as another measure of financial volatility. We also consider the standard deviations of liquid liabilities and bank assets over the same period as alternative volatility proxies of financial development. These regressions reported in Table 6 demonstrate that financial (banks) development continues to exert a decrease in the volatility of industries with higher needs for external liquidity. All estimated coefficients are significantly negative. Likewise, the estimates on the interaction of liquidity needs with different financial volatility proxies are all significantly positive. Consequently, the results that financial development volatility plays an important role in raising industrial volatility appear robust to alternative financial development volatility measures. 
Second, in Table 7, we assess whether our key results are robust to the use of four alternative measures of liquidity needs -- the cash conversion cycle (columns 1 and 2), the ratio of labor cost to sales (columns 3 and 4), the ratio of short-term debt to sales (columns 5 and 6), and external financial dependence (columns 7 and 8). We interact all these measures with private credit to GDP and its volatility and enter the regressions without and with additional information from the conditioning set. The first row of Table 7 shows that all coefficients on the interactions of the alternative measures of liquidity needs and private credit to GDP appear with a significantly negative effect at the 1-percent level, confirming that industries with higher liquidity needs display larger volatility in countries with less developed financial intermediaries. The second row of Table 7 reports the coefficients on the interaction of the volatility of private credit to GDP and alternative measures of liquidity needs. All coefficients prove significantly positive at the 1-percent level, suggesting that, irrespective of measures of liquidity needs, our main conclusion that financial volatility exerts an adverse (increasing) effect on the industrial volatility continues to hold.

Third, we investigate whether, by adding alternative macroeconomic determinants along with their corresponding volatilities, the significantly positive effect of financial volatility on industrial growth volatility persists. Table 8 reports the results. In particular, we include per capital real GDP and its volatility in column (1), inflation and its volatility in column (2), government spending and its volatility in column (3), trade openness and its volatility in column (4), and finally, all macroeconomic variables and their corresponding volatilities in column (5). The first row of Table 8 confirms that higher financial development reduces industrial growth volatility in sectors with higher liquidity needs. The coefficients are all significantly negative at the 5-percent level or better. The second row shows that all estimates on the variable of financial volatility are significantly positive at the 1-percent level, suggesting that unstable financial development raises growth volatility in industries that depend on more external liquidity. All results confirm our previous findings. 


\section{Conclusion}

In an interesting paper, Raddatz (2006) provides strong and robust evidence, showing that the development of financial intermediaries and stock markets, primarily by smoothing fluctuations of growth in output per firm and secondly by reducing the volatility of the number of firms, reduces the growth volatility of industrial sectors with higher liquidity needs. As a complement, this paper investigates, given the level (mean) of financial development, whether the volatility (standard deviation) of financial development plays a role in affecting the industrial volatility.

Using the approach of Rajan and Zingales (1998) and the data provided by Raddatz (2006), we augment with additional measures on the financial development volatility and generate several interesting observations. First, significant empirical evidence supports the hypothesis that volatile financial development increases the industrial volatility in sectors with higher liquidity needs. Second, the adverse effect of financial volatility on industrial volatility mainly flows through the increase in fluctuations of the growth of real value added per firm, and then, to a lesser extent, through the increase in the volatility of the number of firms growth. Third, while the existing literature often finds that financial structure does not affect output growth, we report evidence that both volatilities of the banking system and stock markets positively and significantly associate with higher industrial volatility in sectors that depend on more external liquidity. Further analysis shows that our findings remain robust to different volatility measures of financial development, alternative indicators of liquidity needs, and the inclusion of key macroeconomic variables along with their volatilities. 


\section{References:}

Acemoglu. D., Johnson, S., Robinson, J. A. and ThaiCharoen, Y. (2003), "Institutional Causes, Macroeconomic Symptoms: Volatility, Crises and Growth.” Journal of Monetary Economics 50, 49-123.

Acemoglu. D. and Zilibotti, F. (1997), "Was Prometheous Unbound by Change? Risk, Diversification, and Growth.” Journal of Political Economy 105, 709-751.

Aghion, P., Angeletos, G., Banerjee, A. and Manova, K. (2010), "Volatility and Growth: Credit Constraints and the Composition of Investment.” Journal of Monetary Economics 57, 246- 265.

Aghion, P., Bacchetta, P. and Banerjee, A. (2004), "Financial Development and the Instability of Open Economies.” Journal of Monetary Economics 51, 1077-1106.

Andrés, J., Domeńech, R. and Fatás, A. (2008), “The Stabilizing Role of Government Size.” Journal of Economic Dynamics and Control 32, 571-593.

Ang, J. B. (2008), “A Survey of Recent Developments in the Literature of Finance and Growth.” Journal of Economic Surveys 22, 536-576.

Bacchetta, P. and Caminal, R. (2000), "Do Capital Market Imperfections Exacerbate Output Fluctuations?” European Economic Review 44, 449-468.

Beck, T. (2009), “The Econometrics of Finance and Growth.” In K. Patterson \& T. C. Mills (Eds.), The Palgrave Handbook of Econometrics, 2, 1180-1212. Basingstoke: Palgrave Macmillan.

Beck, T., Demirgüç-Kunt, A., Laeven, L. and Levine, R. (2008), “Finance, Firm Size, and Growth.” Journal of Money, Credit and Banking 40, 1379-1405.

Beck, T., Demirgüç-Kunt, A. and Levine, R. (2000), “A New Database on the Structure and Development of the Financial Sector.” World Bank Economic Review, 14, 597-605.

Beck, T., Demirgüç-Kunt, A. and Levine, R. (2010), "Financial Institutions and Markets across Countries and over Time: The Updated Financial Development and Structure Database.” World Bank Economic Review, 24, 77-92.

Beck, T. and Levine, R. (2002), "Industry Growth and Capital Allocation: Does Having a Marketor Bank-Based System Matter?” Journal of Financial Economics 64, 147-180. 
Beck, T. and Levine, R. (2004), “Stock Markets, Banks and Growth: Panel Evidence.” Journal of Banking \& Finance 28, 423-442.

Beck, T., Levine, R. and Loayza, N. (2000), “Finance and the Sources of Growth.” Journal of Financial Economics 58, 261-300.

Beck, T., Lundberg, M. and Majnoni, G. (2006), "Financial Intermediary Development and Growth Volatility: Do Intermediaries Dampen or Magnify Shocks?.” Journal of International Money and Finance 25, 1146-1167.

Bekaert, G., Harvey, C. R. and Lundblad, C. (2006), "Growth Volatility and Financial Liberalization.” Journal of International Money and Finance 25, 370-403.

Bencivenga, V. R. and Smith, B. D. (1991), “Financial Intermediation and Endogenous Growth.” Review of Economic Studies 58, 195-209.

Benigno, P. and Ricci, L. A. (2010), “The Inflation-Output Trade-Off with Downward Wage Rigidities.” Forthcoming in American Economic Review.

Bernanke, B. and Gertler, M. (1989), “Agency Costs, Net Worth, and Business Fluctuations.” American Economic Review 79, 14-31.

Blanchard, O. and Simon, J. (2001), “The Long and Large Decline in U.S. Output Volatility.” Brookings Papers on Economic Activity 1, 135-174.

Braun, M. and Larrain, B. (2005), "Finance and the Business Cycle: International Inter-Industry Evidence.” Journal of Finance 60, 1097-1128.

Breen, R. and García - Peñalosa, C. (2005), "Income Inequality and Macroeconomic Volatility: An Empirical Investigation.” Review of Development Economics 9, 380-398.

Cetorelli, N. and Gambera, M. (2001), "Banking Market Structure, Financial Dependence and Growth: International Evidence from Industry Data.” Journal of Finance 56, 617-648.

Claessens, S. and Laeven, L. (2003), “Financial Development, Property Rights, and Growth” Journal of Finance 58, 2401-2436. 
Claessens, S. and Laeven, L. (2005), "Financial Dependence, Banking Sector Competition, and Economic Growth” Journal of the European Economic Association 3, 179-207.

Demirgüç - Kunt, A. and Maksimovic, V. (2002), "Funding Growth in Bank-Based and Market-Based Financial Systems: Evidence from Firm Level Data.” Journal of Financial Economics 65, 337-363.

Denizer, C. A., Iyigun, M. F. and Owen, A. (2002), "Finance and Macroeconomic Volatility” Contributions to Macroeconomics, 2, Article 7.

di Giovanni, J. and Levchenko, A. A. (2009), “Trade Openness and Volatility.” Review of Economics and Statistics 91, 558-585.

Dotsey, M. and Sarte, P. D. (2000), "Inflation Uncertainty and Growth in a Cash-in-Advance Economy." Journal of Monetary Economics 45, 631-655.

Eggers, A. and Ioannides, Y. M. (2006), "The Role of Output Composition in the Stabilization of US Output Growth.” Journal of Macroeconomics 28, 585-595.

Fatás, A. and Mihov, I. (2001), “Government Size and Automatic Stabilizers: International and Intranational Evidence.” Journal of International Economics 55, 3-28.

Fatás, A. and Mihov, I. (2012), "Policy Volatility, Institutions and Economic Growth.” Review of Economics and Statistics, forthcoming.

Fountas, S., Karanasos, M. and Kim, J. (2006), "Inflation Uncertainty, Output Growth Uncertainty and Macroeconomic Performance.” Oxford Bulletin of Economics and Statistics 68, 319-343.

Goldsmith, R.W. (1969), Financial Structure and Development. New Haven, CT: Yale University Press.

Greenwood, J. and Jovanovic, B. (1990), "Financial Development, Growth, and the Distribution of Income.” Journal of Political Economy 98, 1076-1107.

Gupta, N. and Yuan, K. (2009), “On the Growth Effect of Stock Market Liberalizations.” Review of Financial Studies 22, 4715-4752.

Hnatkovska, V. and Loayza, N. (2005), "Volatility and Growth.” In Managing Economic Volatility and Crises: A Practitioner's Guide, Ed. by Joshua Aizenman and Brian Pinto, Cambridge: Cambridge University Press. 
Khan, A. (2001), “Financial Development and Economic Growth.” Macroeconomic Dynamics, 5, 413-433.

King, R. G. and Levine, R. (1993a), "Finance, Entrepreneurships, and Growth-Theory and Evidence.” Journal of Monetary Economics 32, 513-542.

King, R. G. and Levine, R. (1993b), “Finance and Growth: Schumpeter Might Be Right.” Quarterly Journal of Economics 108, 717-738.

Kiyotaki, N. and Moore, J. (1997), “Credit Cycles.” Journal of Political Economy 105, 211-248.

Koren, M. and Tenreyro, S. (2007), “Volatility and Development.” Quarterly Journal of Economics 122, 243-287.

Kose, M. A., Prasad, E. S. and Terrones, M. E. (2005), “Growth and Volatility in an Era of Globalization.” IMF Staff Papers 52, 31-63.

Kose, M. A., Prasad, E. S. and Terrones, M. E. (2006), “How Do Trade and Financial Integration Affect the Relationship between Growth and Volatility?” Journal of International Economics 69, 176-202.

Kroszner, R. S., Laeven, L. and Klingeniel, D. (2007), "Banking Crises, Financial Dependence, and Growth.” Journal of Financial Economics 84, 187-228.

La Porta, R., Lopez-de-Silanes, F., Shleifer, A. and Vishny, R. W. (1997), "Legal Determinants of External Finance.” Journal of Finance 52, 1131-1150.

La Porta, R., Lopez-de-Silanes, F., Shleifer, A. and Vishny, R. W. (1998), “Law and Finance.” Journal of Political Economy 106, 1113-1155.

Larrain, B. (2006), “Do Banks Affect the Level and Composition of Industrial Volatility?” Journal of Finance 61, 1897-1925.

Levchenko, A. A., Ranciere, R. and Thoenig, M. (2009), "Growth and Risk at the Industry Level: The Real Effects of Financial Liberalization.” Journal of Development Economics 89, 210-222.

Levine, R. (1997), "Financial Development and Economic Growth: Views and Agenda.” Journal of Economic Literature 35, 688-726.

Levine, R. (2002), “Bank-Based or Market-Based Financial Systems: Which Is Better?” Journal of Financial Intermediation 11, 398-428. 
Levine, R. (2005), "Finance and Growth: Theory and Evidence.” In Aghion, P. and Durlauf, S. N. (Eds), Handbook of Economic Growth, vol. 1A, 865-934. Elsevier, Amsterdam.

Levine, R., Loayza, N. and Beck, T. (2000), "Financial Intermediation and Growth: Causality and Causes.” Journal of Monetary Economics 46, 31-77.

Levine, R. and Zervos, S. (1998), "Stock Markets, Banks, and Economic Growth.” American Economic Review 88, 537-558.

Lin, P. C. and Huang, R. H. C. (2012), “Banking Industry Volatility and Growth.” Journal of Macroeconomics, forthcoming.

Loayza, N. and Ranciere, R. (2006), “Financial Development, Financial Fragility, and Growth.” Journal of Money, Credit and Banking 38, 1051-1076.

McCaig, B. and Stengos, T. (2005), "Financial Intermediation and Growth: Some Robustness Results." Economics Letters 88, 306-312.

Mishkin, F. S. (2009), “Globalization, Macroeconomic Performance, and Monetary Policy.” Journal of Money, Credit and Banking 41, 187-196.

Morgan, D. P., Rime, B. and Strahan, P. E. (2004), "Bank Integration and the State Business Cycles." Quarterly Journal of Economics 119, 1555-1584.

Pindyck, R. (1991). “Irreversibility, Uncertainty, and Investment.” Journal of Economic Literature 29, 1110-1148.

Raddatz, C. (2006), “Liquidity Needs and Vulnerability to Financial Underdevelopment.” Journal of Financial Economics 80, 677-722.

Rajan, R. G. and Zingales, L. (1998), “Financial Dependence and Growth.” American Economic Review 88, 559-586.

Ramey, G. and Ramey, V. A. (1995), “Cross-Country Evidence on the Link between Volatility and Growth.” American Economic Review 85, 1138-1151.

Yellen, J. L. and Akerlof, G. A. (2006), “Stabilization Policy: A Reconsideration.” Economic Inquiry 44, $1-22$. 
Table 1: Summary Statistics

\begin{tabular}{|c|c|c|c|c|c|}
\hline Country-Industry Level Variables & Mean & Std. Dev. & Min & $\overline{\text { Max }}$ & Obs. \\
\hline Standard deviation of the growth of real value added & 0.2710 & 0.1829 & 0.0291 & 1.0039 & 2463 \\
\hline Industry's initial share of total manufacturing value added & 0.0159 & 0.0278 & 0.0000 & 0.4079 & 2463 \\
\hline Log of industry's initial number of firms & 3.8464 & 1.8563 & 0.0000 & 10.0077 & 2381 \\
\hline Variance of real value added per firm growth & 0.1073 & 0.1561 & 0.0000 & 1.4538 & 2410 \\
\hline Variance of number of firms growth & 0.0405 & 0.0699 & 0.0000 & 0.6849 & 2410 \\
\hline Covariance of real value added per firm and number of firms growth & -0.0231 & 0.0506 & -0.5247 & 0.0985 & 2333 \\
\hline \multicolumn{6}{|l|}{ Industry Level Variables } \\
\hline Inventories over sales & 0.1616 & 0.0535 & 0.0526 & 0.3032 & 2390 \\
\hline Cash conversion cycle & 1.0181 & 0.3740 & 0.1900 & 1.9800 & 2390 \\
\hline Labor costs over sales & 0.1821 & 0.0746 & 0.0200 & 0.3500 & 2361 \\
\hline Short-term debt over sales & 0.0123 & 0.0144 & 0.0000 & 0.0700 & 2390 \\
\hline External dependence & 0.1711 & 0.4086 & -1.5300 & 1.4700 & 2390 \\
\hline \multicolumn{6}{|l|}{ Country Level Variables } \\
\hline Private credit to GDP & 0.5213 & 0.319 & 0.0365 & 1.4372 & 2438 \\
\hline Stock market capitaliztion & 0.3340 & 0.3923 & 0.0109 & 1.8584 & 2453 \\
\hline Volatility of private credit to GDP & 0.1198 & 0.0832 & 0.0152 & 0.3474 & 2438 \\
\hline Volatility of stock market capitalization & 0.1539 & 0.1585 & 0.0014 & 0.8221 & 2395 \\
\hline
\end{tabular}


Table 2: Indicators of Financial Development and Volatility

\begin{tabular}{|c|c|c|c|c|}
\hline \multirow[b]{2}{*}{ Country } & \multirow[b]{2}{*}{$\begin{array}{c}\text { Private Credit to } \\
\text { GDP }\end{array}$} & \multirow[b]{2}{*}{$\begin{array}{l}\text { Stock Market } \\
\text { Capitalization }\end{array}$} & \multicolumn{2}{|c|}{ Volatility of } \\
\hline & & & $\begin{array}{c}\text { Private Credit to } \\
\text { GDP }\end{array}$ & $\begin{array}{l}\text { Stock Market } \\
\text { Capitalization }\end{array}$ \\
\hline Australia & 0.4758 & 0.5858 & 0.1794 & 0.1414 \\
\hline Austria & 0.8203 & 0.1235 & 0.0875 & 0.0362 \\
\hline Bangladesh & 0.1960 & 0.0288 & 0.0388 & 0.0242 \\
\hline Cameroon & 0.2006 & -- & 0.0851 & -- \\
\hline Canada & 0.8445 & 0.5896 & 0.0947 & 0.1670 \\
\hline Chile & 0.5088 & 0.4781 & 0.0848 & 0.3217 \\
\hline Colombia & 0.2903 & 0.0773 & 0.0476 & 0.0626 \\
\hline Costa Rica & 0.1562 & 0.0618 & 0.0411 & 0.0141 \\
\hline Côte d'Ivorie & 0.3184 & 0.0637 & 0.0882 & 0.0254 \\
\hline Cyprus & 0.8625 & 0.2086 & 0.2997 & 0.0427 \\
\hline Ecuador & 0.2141 & 0.0894 & 0.0569 & 0.0303 \\
\hline Egypt & 0.2577 & 0.1127 & 0.0614 & 0.0789 \\
\hline Fiji & 0.3146 & 0.0392 & 0.0736 & 0.0124 \\
\hline Finland & 0.6393 & 0.3400 & 0.1605 & 0.2286 \\
\hline France & 0.8007 & 0.3426 & 0.0935 & 0.0956 \\
\hline Germany & 0.9133 & 0.2501 & 0.0923 & 0.0811 \\
\hline Ghana & 0.0365 & 0.1534 & 0.0182 & 0.1009 \\
\hline Greece & 0.3464 & 0.0871 & 0.0454 & 0.0814 \\
\hline Honduras & 0.2979 & 0.0780 & 0.0486 & -- \\
\hline Hong Kong & 1.4372 & 1.8584 & 0.1713 & 0.6014 \\
\hline Iceland & 0.4027 & 0.1813 & 0.1047 & 0.0938 \\
\hline India & 0.2323 & 0.1523 & 0.0152 & 0.1276 \\
\hline Indonesia & 0.3219 & 0.0917 & 0.1622 & 0.1234 \\
\hline Jordan & 0.6337 & 0.5562 & 0.0889 & 0.1201 \\
\hline Korea & 0.8559 & 0.2323 & 0.2507 & 0.1541 \\
\hline Kuwait & 0.5907 & 0.5930 & 0.2736 & 0.1863 \\
\hline Malaysia & 0.9032 & 1.1932 & 0.2865 & 0.8221 \\
\hline Malta & 0.6499 & 0.1108 & 0.2276 & 0.0629 \\
\hline Mauritius & 0.3158 & 0.2866 & 0.0940 & 0.1288 \\
\hline Mexico & 0.1751 & 0.1679 & 0.0760 & 0.1521 \\
\hline Netherlands & 1.0964 & 0.7103 & 0.2936 & 0.3121 \\
\hline Norway & 0.8680 & 0.2584 & 0.1134 & 0.0814 \\
\hline Panama & 0.5115 & 0.1303 & 0.0980 & 0.0851 \\
\hline Peru & 0.1224 & 0.1046 & 0.0762 & 0.0860 \\
\hline & & 27 & & \\
\hline
\end{tabular}


Table 2: Indicators of Financial Development and Volatility

\begin{tabular}{lcccc}
\hline & & & \multicolumn{2}{c}{ Volatility of } \\
\cline { 4 - 5 } Country & Private Credit to & Stock Market & Private Credit to & Stock Market \\
Philippines & GDP & Capitalization & GDP & Capitalization \\
Portugal & 0.3288 & 0.2883 & 0.1246 & 0.2920 \\
Singapore & 0.6815 & 0.1117 & 0.1444 & 0.1108 \\
Spain & 0.9864 & 1.3202 & 0.1167 & 0.3520 \\
Sri Lanka & 0.7263 & 0.3104 & 0.0479 & 0.1228 \\
Sweden & 0.1803 & 0.1306 & 0.0556 & 0.0554 \\
Trinidad and Tob & 1.0232 & 0.6297 & 0.1782 & 0.2657 \\
Tunisia & 0.4786 & 0.2014 & 0.1007 & 0.1627 \\
Turkey & 0.5852 & 0.1062 & 0.0604 & 0.0626 \\
United Kingdom & 0.1477 & 0.0652 & 0.0216 & 0.0594 \\
Uruguay & 0.8134 & 1.1233 & 0.3474 & 0.2373 \\
Venezuela & 0.2987 & 0.0109 & 0.0963 & 0.0014 \\
Zimbabwe & 0.3430 & 0.0819 & 0.1904 & 0.0539 \\
\hline Note: & -- & 0.1655 & -- & 0.1034 \\
\hline
\end{tabular}

Note: $\quad$ The level (volatility) of banking development and stock market development is measured, respectively, by the mean (standard deviation) of the private credit by deposit money banks and other financial institutions over GDP and stock market capitalization over GDP during the 1980-1998 period. The data set is taken from Beck, Demirgüc - Kunt and Levine (2000, 2010). 
Table 3: The Level and Volatility of Financial Development on Sector Volatility

\begin{tabular}{|c|c|c|c|c|c|c|}
\hline \multirow[b]{2}{*}{ Variables } & \multicolumn{2}{|c|}{ OLS } & \multicolumn{2}{|c|}{ 2SLS(I) } & \multicolumn{2}{|c|}{ 2SLS(II) } \\
\hline & (1) & (2) & (3) & (4) & (5) & (6) \\
\hline Liquidity Needs $_{\mathrm{i}} *$ Private Credit $_{\mathrm{k}}$ & $\begin{array}{c}-0.904^{* * *} \\
(-0.17)\end{array}$ & $\begin{array}{c}-0.694 * * * \\
(-0.17)\end{array}$ & $\begin{array}{c}-1.984^{* * *} \\
(-0.33)\end{array}$ & $\begin{array}{c}-1.526 * * * \\
(-0.31)\end{array}$ & $\begin{array}{c}-2.188^{* * *} \\
(-0.42)\end{array}$ & $\begin{array}{c}-1.764 * * * \\
(-0.40)\end{array}$ \\
\hline Liquidity Needs $_{i}$ * Volatility of Private Credit ${ }_{k}$ & $\begin{array}{c}1.733^{* * *} \\
(0.55)\end{array}$ & $\begin{array}{c}1.723^{* * *} \\
(0.52)\end{array}$ & $\begin{array}{c}4.227^{* * * *} \\
(0.92)\end{array}$ & $\begin{array}{c}3.614^{* * *} \\
(0.85)\end{array}$ & $\begin{array}{c}4.680^{* * *} \\
(1.10)\end{array}$ & $\begin{array}{c}4.160^{* * *} \\
(1.03)\end{array}$ \\
\hline${\text { Industry's initial share of total manufacturing value } \text { added }_{i k}}$ & & $\begin{array}{c}-0.549 * * * \\
(-0.13)\end{array}$ & & $\begin{array}{c}-0.529 * * * \\
(-0.13)\end{array}$ & & $\begin{array}{c}-0.516^{* * *} \\
(-0.13)\end{array}$ \\
\hline Log of industry's initial number of firms $s_{i k}$ & & $\begin{array}{c}-0.028 * * * \\
(-0.00)\end{array}$ & & $\begin{array}{c}-0.027 * * * \\
(-0.00)\end{array}$ & & $\begin{array}{c}-0.027 * * * \\
(-0.00)\end{array}$ \\
\hline Country dummies & Yes & Yes & Yes & Yes & Yes & Yes \\
\hline Industry dummies & Yes & Yes & Yes & Yes & Yes & Yes \\
\hline Differential Volatility: Private Credit to $\mathbf{G D P}_{\mathbf{k}}$ & -3.297 & -2.531 & -7.236 & -5.566 & -7.980 & -6.434 \\
\hline $\begin{array}{l}\text { Differential Volatility: Volatility of Private Credit } \\
\text { P-value of overidentification test }\end{array}$ & 1.322 & 1.314 & $\begin{array}{c}3.225 \\
{[0.285]}\end{array}$ & $\begin{array}{c}2.757 \\
{[0.123]}\end{array}$ & $\begin{array}{c}3.57 \\
{[0.397]}\end{array}$ & $\begin{array}{c}3.173 \\
{[0.691]}\end{array}$ \\
\hline Observations & 2315 & 2239 & 2315 & 2239 & 2286 & 2210 \\
\hline
\end{tabular}

Note: $\quad$ The dependent variable is the standard deviation of real value added growth $\left(V_{i k}^{G}\right)$ during the 1981-1998 period for each 4-digit ISIC industry in each country. Liquidity Needs $\left(L N_{i}\right)$ is the median ratio of total inventories over annual sales for U.S. corporate firms in each 4-digit industry between 1980-1989. The level and volatility of banking development $\left(D E V_{k}^{F}\right.$ and $V_{k}^{F}$ ) are, respectively, measured by the mean and standard deviation of the private credit by deposit money banks and other financial institutions over GDP (Private Credit and Volatility of Private Credit) over the 1980-1998 period. Columns 1 and 2 display the OLS results, Columns 3 and 4 present the 2SLS results when banking development is instrumented using a country's legal origin, and columns 5 and 6 report the 2SLS results when banking development is instrumented using a country's legal origin and the liquidity needs is instrumented using the ratio of inventory to sales observed during the 1970s. The Differential Volatility measures the difference in sectoral volatility between an industry at the 75th percentile level of liquidity needs with respect to an industry at the 25th percentile level when it is located in a country at the $75^{\text {th }}$ percentile of (the volatility of) banking development rather than in one at the 25th percentile. Country and industry fixed effects are included in all regressions but not reported. The heteroskedasticity-robust standard errors are reported in parentheses. ${ }^{* * *}$ indicates significant at $1 \%$ level. 


\section{Stock Markets Development ${ }_{k}$ Measured as}

\begin{tabular}{|c|c|c|c|c|c|c|}
\hline \multirow{2}{*}{ Variables } & & & & & & \\
\hline & (1) & (2) & (3) & (4) & (5) & (6) \\
\hline \multirow{2}{*}{ Liquidity Needs $_{\mathrm{i}} *$ Private Credit $_{\mathrm{k}}$} & $-1.209 * * *$ & $-1.137 * * *$ & $-1.208^{* * *}$ & $-1.016^{* *}$ & $-1.323 * * *$ & $-1.411 * * *$ \\
\hline & $(-0.25)$ & $(-0.24)$ & $(-0.43)$ & $(-0.41)$ & $(-0.49)$ & $(-0.46)$ \\
\hline \multirow[t]{2}{*}{ Liquidity Needs $_{i}$ * Stock Market Development ${ }_{k}$} & -0.364 & -0.056 & $-0.814 *$ & -0.593 & $-4.549 * *$ & -2.108 \\
\hline & $(-0.33)$ & $(-0.32)$ & $(-0.45)$ & $(-0.42)$ & $(-1.96)$ & $(-1.86)$ \\
\hline \multirow[t]{2}{*}{ Liquidity Needs $_{\mathrm{i}} *$ Volatility of Private Credit ${ }_{\mathrm{k}}$} & $2.035^{* * *}$ & $1.928 * * *$ & $2.845^{* * *}$ & $2.771^{* * *}$ & $3.588^{* * *}$ & $3.072 * * *$ \\
\hline & $(0.62)$ & $(0.58)$ & $(0.91)$ & $(0.87)$ & $(0.87)$ & $(0.79)$ \\
\hline \multirow[t]{2}{*}{ Liquidity Needs $_{\mathrm{i}} *$ Volatility of Stock Market Development $\mathrm{k}_{\mathrm{k}}$} & $1.543^{* * *}$ & $1.157^{* *}$ & $1.026 * *$ & $0.804^{*}$ & $5.610^{* * *}$ & $3.524^{* *}$ \\
\hline & $(0.59)$ & $(0.58)$ & $(0.49)$ & $(0.47)$ & $(1.82)$ & $(1.72)$ \\
\hline \multirow[t]{2}{*}{ Industry's initial share of total manufacturing value added $_{i k}$} & & $-0.545^{* * *}$ & & $-0.560 * * *$ & & $-0.535 * * *$ \\
\hline & & $(-0.13)$ & & $(-0.13)$ & & $(-0.13)$ \\
\hline \multirow[t]{2}{*}{ Log of industry's initial number of firms ${ }_{i k}$} & & $-0.027 * * *$ & & $-0.027 * * *$ & & $-0.026 * * *$ \\
\hline & & $(-0.00)$ & & $(-0.00)$ & & $(-0.00)$ \\
\hline Country dummies & Yes & Yes & Yes & Yes & Yes & Yes \\
\hline Industry dummies & Yes & Yes & Yes & Yes & Yes & Yes \\
\hline Differential Volatility: Volatility of Private Credit $_{k}$ & 1.552 & 1.471 & 2.17 & 2.114 & 2.737 & 2.343 \\
\hline Differential Volatility: Volatility of Stock Market Development $_{k}$ & 1.109 & 0.832 & 1.328 & 1.041 & 4.908 & 3.083 \\
\hline P-value of overidentification test & {$[0.183]$} & {$[0.152]$} & [0.569] & [0.224] & [0.177] & [0.129] \\
\hline Observations & 2250 & 2174 & 2194 & 2118 & 2221 & 2145 \\
\hline
\end{tabular}

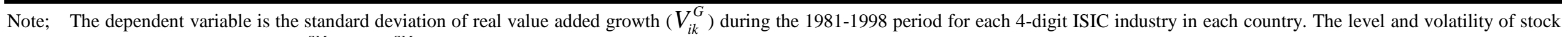
markets development ( $D E V_{k}^{S M}$ and $V_{k}^{S M}$ ) are, respectively, measured by the mean and standard deviation of (i) stock market capitalization as a ratio of GDP, (ii) stock markets total value traded over GDP, and (iii) stock market turnover ratio during the 1980-1998 period. All results are obtained using the 2SLS approach with alternative set of instrumental variables. Please see the footnote of Table 3 for other related information. ***, **, and * indicates significant at $1 \%, 5 \%$ and $10 \%$ level, respectively. 


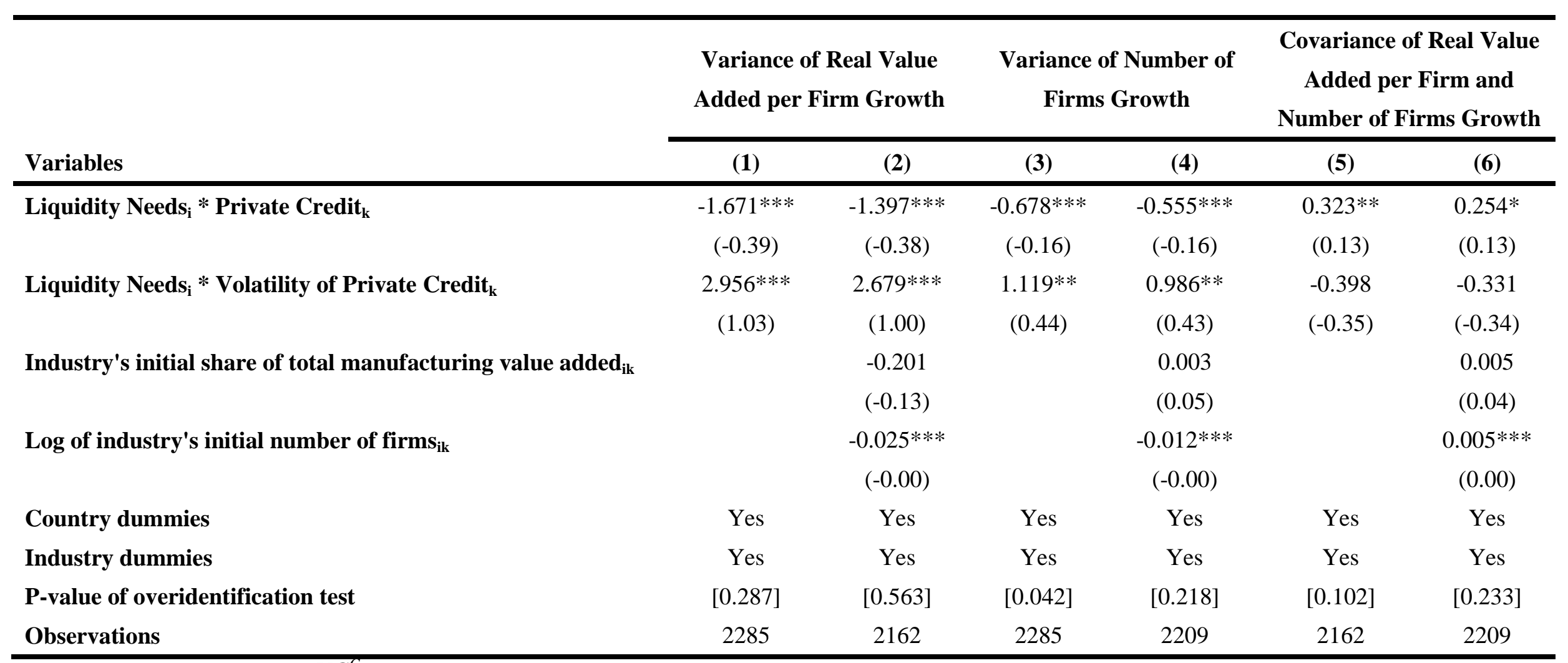

Note: $\quad$ The dependent variable $\left(V C_{i k}^{G}\right)$ is (i) the variance of real value added per firm growth, (ii) the variance of number of firms growth, and (iii) the covariance of real value added per firm growth and number of firms growth, respectively, during the 1981-1998 period for each 4-digit ISIC industry in each country. Please see the footnote of Table 3 for other related information. ***, **, and * indicates significant at $1 \%, 5 \%$ and $10 \%$ level, respectively. 


\begin{tabular}{|c|c|c|c|c|c|c|}
\hline \multirow[b]{3}{*}{ Variables } & \multicolumn{6}{|c|}{ Volatility of Bank Development $t_{k}$ Measured as } \\
\hline & \multicolumn{2}{|c|}{ Range of Private Credit } & \multicolumn{2}{|c|}{$\begin{array}{l}\text { Standard Deviation of } \\
\text { Liquid Liabilities }\end{array}$} & \multicolumn{2}{|c|}{$\begin{array}{c}\text { Standard Deviation of } \\
\text { Bank Assets }\end{array}$} \\
\hline & (1) & (2) & (3) & (4) & (5) & (6) \\
\hline Liquidity Needs $_{\mathrm{i}} *$ Bank Development $_{\mathrm{k}}$ & $\begin{array}{c}-2.300 * * * \\
(-0.38)\end{array}$ & $\begin{array}{c}-1.803^{* * *} \\
(-0.36)\end{array}$ & $\begin{array}{c}-3.537 * * * \\
(-0.82)\end{array}$ & $\begin{array}{c}-2.287 * * * \\
(-0.77)\end{array}$ & $\begin{array}{c}-1.438 * * \\
(-0.43)\end{array}$ & $\begin{array}{c}-0.838 * * \\
(-0.42)\end{array}$ \\
\hline Liquidity Needs $_{i}$ * Volatility of Bank Development $t_{k}$ & $\begin{array}{c}1.754^{* * * *} \\
(0.34)\end{array}$ & $\begin{array}{c}1.506^{* * *} \\
(0.32)\end{array}$ & $\begin{array}{c}10.833^{* * *} \\
(2.33)\end{array}$ & $\begin{array}{c}8.001^{* * *} \\
(2.16)\end{array}$ & $\begin{array}{c}5.591^{* * *} \\
(1.78)\end{array}$ & $\begin{array}{c}3.998 * * \\
(1.68)\end{array}$ \\
\hline Industry's initial share of total manufacturing value added $_{i k}$ & & $\begin{array}{c}-0.525^{* * *} \\
(-0.13)\end{array}$ & & $\begin{array}{c}-0.473^{* * *} \\
(-0.14)\end{array}$ & & $\begin{array}{c}-0.339 * * * \\
(-0.13)\end{array}$ \\
\hline Log of industry's initial number of firms ${ }_{i k}$ & & $\begin{array}{c}-0.027^{* * *} \\
(-0.00)\end{array}$ & & $\begin{array}{c}-0.027 * * * \\
(-0.00)\end{array}$ & & $\begin{array}{c}-0.030 * * * \\
(-0.00)\end{array}$ \\
\hline Country dummies & Yes & Yes & Yes & Yes & Yes & Yes \\
\hline Industry dummies & Yes & Yes & Yes & Yes & Yes & Yes \\
\hline P-value of overidentification test & [0.688] & [0.345] & [0.208] & [0.122] & {$[0.118]$} & [0.359] \\
\hline Observations & 2315 & 2239 & 2207 & 2131 & 1417 & 1356 \\
\hline
\end{tabular}


Liquidity Needs Measured as

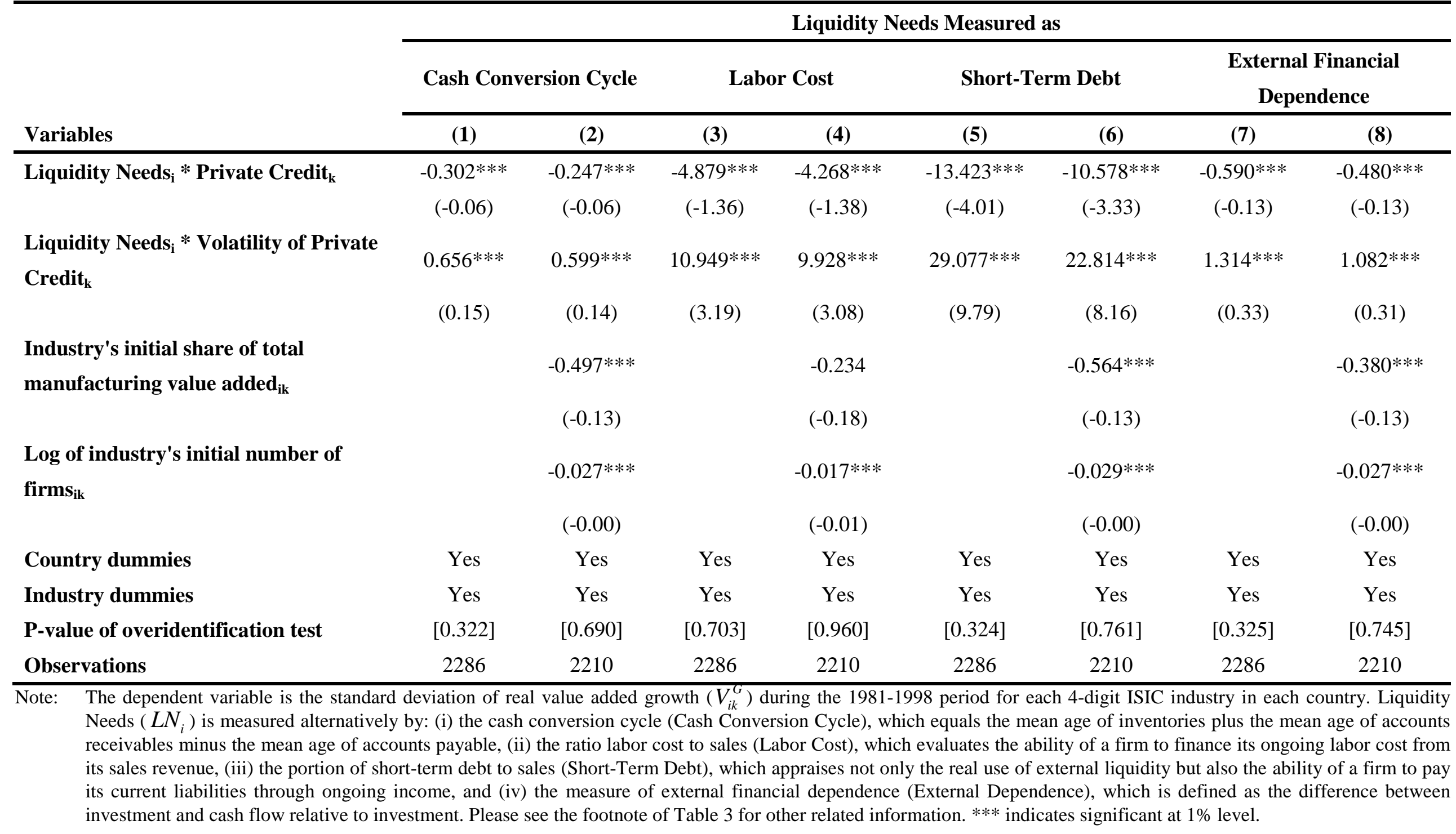


Table 8: Alternative Controlling Variables

\begin{tabular}{|c|c|c|c|c|c|}
\hline Variables & (1) & (2) & (3) & (4) & (5) \\
\hline Liquidity Needs $_{\mathrm{i}}$ * Private Credit ${ }_{\mathrm{k}}$ & $\begin{array}{c}-2.464 * * * \\
(-0.82)\end{array}$ & $\begin{array}{c}-2.104 * * * \\
(-0.66)\end{array}$ & $\begin{array}{c}-2.060 * * * \\
(-0.79)\end{array}$ & $\begin{array}{c}-1.772^{* * *} \\
(-0.53)\end{array}$ & $\begin{array}{c}-3.096 * * \\
(-1.56)\end{array}$ \\
\hline $\begin{array}{l}\text { Liquidity Needs }_{\mathrm{i}} * \text { Volatility of } \\
\text { Private Credit }_{\mathrm{k}}\end{array}$ & $\begin{array}{c}3.323 * * * \\
(0.91)\end{array}$ & $\begin{array}{c}4.555^{* * *} \\
(1.26)\end{array}$ & $\begin{array}{c}4.796^{* * *} \\
(1.54)\end{array}$ & $\begin{array}{c}3.045^{* * *} \\
(0.85)\end{array}$ & $\begin{array}{c}3.021 * * * \\
(1.10)\end{array}$ \\
\hline $\begin{array}{l}\text { Liquidity Needs }_{\mathrm{i}} * \text { Log Per Capita } \\
\text { GDP }_{\mathbf{k}}\end{array}$ & $\begin{array}{l}-0.139 \\
(-0.11)\end{array}$ & & & & $\begin{array}{l}0.150 \\
(0.19)\end{array}$ \\
\hline $\begin{array}{l}\text { Liquidity Needs }_{i} * \text { Volatility of Log } \\
\text { Per Capita } \text { GDP }_{k}\end{array}$ & $\begin{array}{c}0.420^{* * *} \\
(0.14)\end{array}$ & & & & $\begin{array}{l}0.327^{*} \\
(0.17)\end{array}$ \\
\hline Liquidity Needs $_{\mathrm{i}} *$ Inflation $_{\mathrm{k}}$ & & $\begin{array}{l}-0.042 \\
(-0.14)\end{array}$ & & & $\begin{array}{l}-0.055 \\
(-0.17)\end{array}$ \\
\hline $\begin{array}{l}\text { Liquidity Needs }_{\mathbf{i}} * \text { Volatility of } \\
\text { Inflation }_{\mathbf{k}}\end{array}$ & & $\begin{array}{l}-0.069 \\
(-0.11)\end{array}$ & & & $\begin{array}{l}-0.098 \\
(-0.13)\end{array}$ \\
\hline $\begin{array}{l}\text { Liquidity Needs }_{i} * \text { Government } \\
\text { Spending }_{k}\end{array}$ & & & $\begin{array}{l}-0.022 \\
(-0.28)\end{array}$ & & $\begin{array}{c}-0.467^{*} \\
(-0.27)\end{array}$ \\
\hline $\begin{array}{l}\text { Liquidity Needs }_{\mathrm{i}} * \text { Volatility of } \\
\text { Gov't Spending }_{\mathrm{k}}\end{array}$ & & & $\begin{array}{l}-0.154 \\
(-0.14)\end{array}$ & & $\begin{array}{l}-0.172 \\
(-0.15)\end{array}$ \\
\hline Liquidity Needs $_{\mathrm{i}} *$ Trade Openness $_{\mathrm{k}}$ & & & & $\begin{array}{l}0.428 * \\
(0.26)\end{array}$ & $\begin{array}{l}0.275 \\
(0.20)\end{array}$ \\
\hline $\begin{array}{l}\text { Liquidity Needs }_{\mathrm{i}} * \text { Volatility of } \\
\text { Trade Openness }_{\mathrm{k}}\end{array}$ & & & & $\begin{array}{l}-0.034 \\
(-0.14)\end{array}$ & $\begin{array}{l}0.253 \\
(0.20)\end{array}$ \\
\hline Other Controls & Yes & Yes & Yes & Yes & Yes \\
\hline Country dummies & Yes & Yes & Yes & Yes & Yes \\
\hline $\begin{array}{l}\text { Industry dummies } \\
\text { P-value of overidentification test }\end{array}$ & $\begin{array}{c}\text { Yes } \\
{[0.729]}\end{array}$ & $\begin{array}{c}\text { Yes } \\
{[0.680]}\end{array}$ & $\begin{array}{c}\text { Yes } \\
{[0.907]}\end{array}$ & $\begin{array}{c}\text { Yes } \\
{[0.575]}\end{array}$ & $\begin{array}{c}\text { Yes } \\
{[0.842]}\end{array}$ \\
\hline Observations & 2210 & 2210 & 2210 & 2157 & 2157 \\
\hline
\end{tabular}

Note: $\quad$ The dependent variable is the standard deviation of real value added growth $\left(V_{i k}^{G}\right)$ during the 1981-1998 period for each 4-digit ISIC industry in each country. Please see the footnote of Table 3 for other related information. ${ }^{* * *}, * *$ and $*$ indicates significant at $1 \%, 5 \%$ and $10 \%$, respectively. 